\title{
A ENFERMAGEM E OS MÚLTIPLOS RISCOS CONTEMPORÂNEOS: DESAFIOS E PERSPECTIVAS
}

Eliana Auxiliadora Costa

Email para correspondência: Eliana Auxiliadora Costa - costaeliana2003@hotmail.com Doutora em Saúde Coletiva. Professora da Escola de Enfermagem da Universidade do Estado da Bahia. Salvador, Bahia, Brasil.

\begin{abstract}
...não conto os que morrem velhos na América Latina, esses são poucos; os homens aqui mal passam dos trinta Não conto os mortos de faca nem os mortos de polícia; conto os que morrem de febre e os que morrem de tísica;

Conto os que morrem de bouba, de tifo, de verminose; conto os que morrem de crupe, de cancro e schistosomose.

Mas todos esses defuntos, morrem de fato é de fome quer a chamemos de febre ou de qualquer outro nome

Morrem de fome e miséria quatro homens por minuto embora enriqueçam outros que deles não sabem muito"

Ferreira Gullar - Morrem quatro por minuto
\end{abstract}

Estamos em crise. Ética, moral, política e institucional. Individual e coletiva. Vivemos a ameaça de riscos variados que se renovam a cada dia e incertezas que nos afetam onde quer que vivamos, não importa quão privilegiados ou carentes sejamos.

Paira sobre nós a possibilidade de perdas de direitos e conquistas já consolidados, como as tentativas de diminuição do direito constitucional à saúde universal e gratuita, do trabalho digno, do direito a aposentadoria e até do sagrado prazer de comer carne, dentre muitos outros.

Doenças reemergentes e que imaginávamos controladas, a exemplo da febre amarela e outras patologias citadas pelo grande poeta Ferreira Gullar, assolam nosso povo combalido por essas e por outras mazelas tão graves quanto, como a desesperança, a descrença generalizada, o medo e a insegurança.

Esse cotidiano turbulento tem reflexos no comportamento das pessoas, das organizações e dos seus processos de trabalho. Como prestar assistência segura ao paciente dentro de um serviço de saúde, frente às inseguranças acima relatadas vivenciadas por todos, inclusive profissionais de saúde, especificamente pelos enfermeiros? Como gerenciar pessoas em tempo de caos generalizado? 
Como exercer a liderança de uma equipe como a da Enfermagem, responsável por mais de $60 \%$ das ações assistenciais de saúde, trabalhando num regime de 24 horas, numa interação contínua com os pacientes, num clima que inclui muita satisfação e alegrias, mas também, dor e sofrimento que emerge desse contexto, quando as ameaças rondam a segurança dos cuidadores? É um desafio enorme!!.

A palavra de ordem é resiliência. Conceito oriundo do campo da física e utilizado em várias áreas de conhecimento e que pode ser entendido como a capacidade humana para enfrentar, superar e se aperfeiçoar quando de experiências desfavoráveis. É a habilidade de transpor adversidades, de responder de forma mais consistente aos desafios e dificuldades, tendo uma atitude otimista, positiva, perseverante.

A resiliência pode ser um atributo individual, mas também organizacional, gerando, assim, uma sociedade mais resistente às crises. Entretanto, para ser resiliente, faz-se necessário um equilíbrio entre exposição aos riscos e fatores de proteção. Esses estão associados às condições do próprio indivíduo/organizações, tais como crenças e valores, mas podem também ser desenvolvidos, com a mobilização, capacidade de ser, estar, ter, poder e querer, ou seja, pela capacidade de autoregulação e auto-estima positiva diante das situações indesejadas.

Acredita-se que a resiliência possa ser construída quando o sujeito se apropria da sua realidade e a transforma, transformando, consequentemente, a si mesmo num momento dialético.

Assim, quanto mais crise, mais resilientes precisamos ser. "O mais bonito de tudo, talvez seja isso, a vida segue"....

Boa leitura. 